\title{
Focalizing the Body in Contemporary Women's Writing and Filmmaking in France, Edited by Gill Rye and Carrie Tarr
}

\section{Emanuele Kanceff}

\section{(2) OpenEdition Journals}

\section{Edizione digitale}

URL: https://journals.openedition.org/studifrancesi/26758

DOI: $10.4000 /$ studifrancesi.26758

ISSN: 2421-5856

\section{Editore}

Rosenberg \& Sellier

\section{Edizione cartacea}

Data di pubblicazione: 1 avril 2007

Paginazione: 210

ISSN: 0039-2944

\section{Notizia bibliografica digitale}

Emanuele Kanceff, «Focalizing the Body in Contemporary Women's Writing and Filmmaking in France, Edited by Gill Rye and Carrie Tarr», Studi Francesi [Online], 151 (LI | I) | 2007, online dal 30 novembre 2015, consultato il 23 novembre 2021. URL: http://journals.openedition.org/studifrancesi/26758 ; DOI: https://doi.org/10.4000/studifrancesi.26758

Questo documento è stato generato automaticamente il 23 novembre 2021.

\section{cc) (†) $\odot$}

Studi Francesi è distribuita con Licenza Creative Commons Attribuzione - Non commerciale - Non opere derivate 4.0 Internazionale. 


\title{
Focalizing the Body in Contemporary Women's Writing and Filmmaking in France, Edited by Gill Rye and Carrie Tarr
}

\author{
Emanuele Kanceff
}

\section{NOTIZIA}

AA. VV., Focalizing the Body in Contemporary Women's Writing and Filmmaking in France, Edited by Gill RYE and Carrie TARR, «Nottingham French Studies», vol 45, n. 3, Autumn 2006, pp. 138.

1 La nota rivista dedica uno dei suoi fascicoli monografici alla "scrittura" del corpo femminile in Francia alla fine del Novecento, dopo i recenti France, America and the Modern (autunno 2005, recensito in questi «Studi») e Revolutionary Culture. Continuity and Change (primavera 2006). In una breve introduzione, le curatrici ricordano gli episodi letterari e filmici più notevoli degli ultimi anni e lo scandalo che al loro apparire hanno provocato. Queste opere discusse, che peraltro sono state dei best-seller venduti anche nei supermercati, non potevano provocare altro che una interpretazione femminile e delle letture critiche numerose, per lo più molto prevenute a causa di un femminismo sensibile e ferito.

2 Ci voleva dunque una messa a punto sulla rappresentazione del corpo femminile nella scrittura e nella filmografia femminile nell'ultimo ventennio e sulle letture critiche che ne sono derivate. Nell'impossibilità di analizzare ogni singolo intervento, ci sembra utile elencarne almeno $i$ contenuti:

3 Introduction (GILL RYE and CARRIE TARR, p 1) - Close-up and Impersonal: Sexual/Textual Bodies in Contemporary French Women's Writing (SHIRLEY JORDAN, p. 8) - Close-up Vision: Re-mapping the Body in the Work of Contemporary French Women Filmmakers 
(MARTINE BEUGNET, p. 24) - Deviant Bodies: Corporeal Otherness in Contemporary Women's Writing (SUSAN IRELAND, p. 39) - Baise-moi or the Ethics of the Desiring Gaze (LISA DownING, p. 52) - L'«écriture de peau»: The Body as Witness in Lorette Nobécourt's La Démangeaison (KATHRYN ROBSON, p. 66) - Director's Cuts: The Aesthetics of Self-harming in Marina de Van's Dans ma peau (CARRIE TARR, p. 78) - Registering Trauma: The Body in Childbirth in Contemporary French Women's Writing (GILL RYE, p. 92) Women Filming Children (EMMA WILSON, p. 105) - Images of the Dead: An Exploration of the Hidden World of Nathalie Rheims's Lumière invisible à mes yeux (MICHAEL WORTON, p. 119) - Notes on Contributors, p. 137. 